\title{
Morphophysiological Effects of Various Foliar Nutrition Regimes in Apple in the South of Russia
}

\author{
L. Buntsevich, N. Sergeyeva* \\ State Scientific Organization North Caucasian Regional Research institute of Horticulture and Viticulture \\ of the Russian Academy Sciences, Krasnodar, Russia \\ *Corresponding Author: sady63@bk.ru
}

Copyright (C) 2014 Horizon Research Publishing All rights reserved.

\begin{abstract}
The features of the morphogenetic development and mode of mineral nutrition of a dwarf apple-tree were investigated against application of foliar nutrition with aqueous solutions of complex mineral fertilizers in the conditions of the south of Russia.
\end{abstract}

Keywords Apple, Morphophysiological Development, Biological Control, Foliar Nutrition, Chemical Diagnostics, Mineral Nutrition

\section{Introduction}

Structural features of perennial vegetative organisms differentiated by a large number of specialized cells, tissues and organs, requires the improvement of productional process control systems and nutrition optimization based on the factors that influence the development of individual organs and the whole plant, especially in a changing environment. In this regard studying the nature of the horticultural crops requirements to the complex of external and internal conditions of the morphogeny process is essential for the realization of practical farming issues, the formation of productive fruit trees and agrocenosis functioning as a whole. In addition, the quantitative study of organogenesis, morphophysiological characteristics of generative shoot formation and fruiting organization and different effects on various abiotic factors of apple tree activity, enhances the theoretical science foundations of the apple tree organogenesis. As is generally known, each of the stages of a seasonal development has a structural, biochemical and functional specificity, in relation to those fruit crops environmental requirements are not identical. Intensity of morphogenetic processes, its duration can vary depending on external conditions. In this case, one of the most available factors for controlling the agrotechnical methods that influence the optimization of the crop formation is mineral nutrition. This requires establishing the feeding regime that is optimal for the appletree, growing in specific soil and climatic conditions, at various stages of organogenesis and determining the responsiveness of the tree to foliar nutrition [1-3].

In this regard, the primary goal of our research was to determine the characteristics of the formation and development of the production potential of the apple tree under the influence of foliar nutrition and aqueous solutions of complex mineral fertilizers in the soil and climatic conditions of the south of Russia.

\section{Materials and Methods}

Research has been ongoing since 2007 in the fruit bearing apple tree plantations that includes the cultivars 'Idared', 'Korej' and 'Prikubanskoe' on M9 rootstock. The tests were conducted at the experimental production farm "Centralnoe" (Krasnodar). The soil type is leached chernozem. The plot was planted in 1996, the layout of the trees is $5 \times 2 \mathrm{~m}$. The trees were trained to a spindle system. Agrotechnical background is common for plants of this type.Biological control of plant development and the study of the generative shoots intrarenal development, the transition to flowering and fruiting was performed by the method of A. Uskova [1] and I. Isaeva [4]. Objects were examined under an "Olympus" VH41microscope and photographed with zoom in $10 x 40$.For foliar nutrition we used a $0.5 \%$ aqueous solution of complex fertilizers, such labels as :1) in the spring-summer period: $18-18-18+\mathrm{Mg}+\mathrm{S}+\mathrm{Zn}, \mathrm{Cu}, \mathrm{Mn}$ (as chelate EDTA), Fe (DTPA), Mo, B (as inorganic compounds) and $12-12-35+\mathrm{Mg}+\mathrm{S}+\mathrm{Zn}, \mathrm{Cu}, \mathrm{Mn}$ (as chelate EDTA), Fe (DTPA), Mo, B (as inorganic compounds) in the summer; 2) 8-8-28 + Zn, Cu, Mn (as chelate EDTA), Mo, B (as inorganic compounds) during the growing season; 3) 16-16-16 $+\mathrm{Zn}$, $\mathrm{Cu}, \mathrm{Mn}$ (as chelate EDTA), Mo, B (as inorganic compounds) during the growing season.

We diagnosed gross content of mineral elements in the leaves of annual increments at the stage of micro-and macrosporogenesis at the completion of the male and female gametophyte formation and regularly during the growth of the fruit in the summer and during the transition from vegetative to generative bud development (in summer).We 
used common methods for chemical diagnostics, based on mineralization of air-dry ashing of plant material, followed by determination of mineral elements by colorimetric methods and flame photometry [5-8].

Chlorophyll content was determined by the spectral method, the content of motile forms of inorganic ion and biochemically active substances were analyzed by tissue instant diagnosis using a special mode of microwave plant extraction by adding $10 \%$ aqueous alcohol [ 9]. Subsequent research samples were carried out using capillary electrophoresis by a modified method for the plant material analysis [ 10-12].

Annual biological observations began three weeks before flowering, during the progression of the morphogenetic processes: i.e. micro- and macrosporogenesis, that completed the formation of the male and female gametophyte. Outwardly these morphogenetic processes in the apple tree appear as two phases: "buds swelling" and "inflorescences telescoping". It was determined that apple vegetative growth was regulated mainly by biotic factors and primarily by air temperature. During the research air temperature fluctuation in April, before apple floral initiation, were considerable and ranged from $1,1{ }^{\circ} \mathrm{C}$ to $28,6{ }^{\circ} \mathrm{C}$. The stabilization of daily average air temperatures in the range of $15-20^{\circ} \mathrm{C}$ stimulates the ovary tissue formation (Figure 1), the growth of the sepal and petal tissue was particularly fast, while development of pistils and stamens was slowing some years we have noted the accelerated development of generative structures with different fertilizers used on 'Idared' in comparison with 'Prikubanskoe и Korej'.

The leaf chemical composition of rosettes during the "budding", "transition to flowering" and "ovary growth" stages were determined. This stage of organogenesis is characterized by the following gross content of mineral elements in the leaves of rosettes: nitrogen - 3,4\%, phosphorus - 0,5-0,6\%, potassium - 1,2-1,7\% calcium $0,4-1,7 \%$, magnesium $-0,2-0,3 \%$ of dry matter. When $18-18-18+\mathrm{Mg}+\mathrm{S}$ and $\mathrm{N} 12 \mathrm{P} 12 \mathrm{~K} 35+\mathrm{Mg}+\mathrm{S}$ fertilizers were applied during the growing season, nitrogen content in the leaves of rosettes was up 3-5\%.

Analysis of gross and mineral forms ratio of the basic elements also identified an advantage of this variant - the content of calcium motile forms and magnesium in the leaves is higher in comparison with the control (without fertilizer) and other fertilizers application (Figure 2).

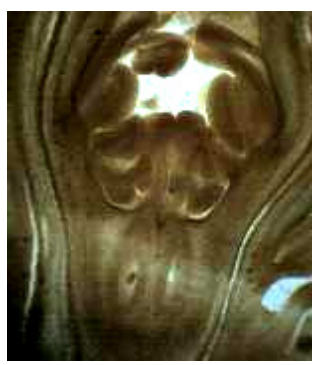

A

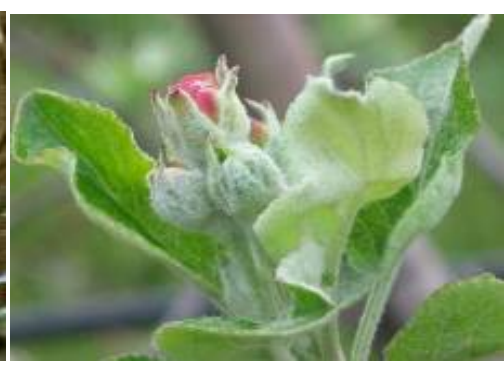

B
Figure 1. A general view of the internal structure of the germinative flower (A) and external display of development stage (B), phase "flower buds isolation"

In the early phases of seasonal development, the most significant differences in motile forms content of nutritional elements in the leaves was defined in comparison to their gross forms, depending on biotic factors, and against foliar nutrition. So we can suppose the possibility of its primary diagnostics.

We summarized the experimental data and it helped to reveal the range of maintenance and find that this stage of the seasonal apple tree development are characterized by a maximum consumption of nutrients, especially nitrogen and potassium, as the products of photosynthesis and minerals are needed for the stage of "flowering-fertilization." The chemical diagnosis results are presented in Table 1.

Particular attention to the content of mineral elements in apple trees was paid during the period of transition to the generative development, when the formation and branching of inflorescence axis begins at the growing point (Figure 3).

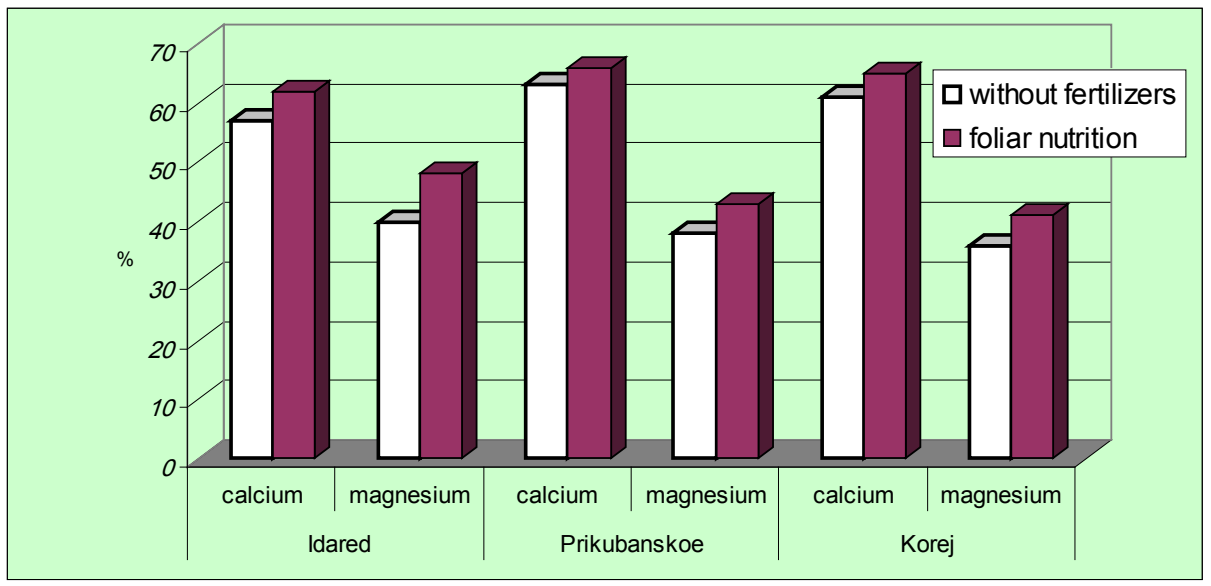

Figure 2. The ratio of mineral and gross forms of elements in apple tree leaves 
Table 1. The content of mineral elements in apple trees leaves of rosettes on M9 rootstock

\begin{tabular}{|c|c|c|c|}
\hline & \multicolumn{2}{|c|}{ Apple tree development phase / stage } & Content of gross forms of elements, \% \\
\hline Nitrogen & «inflorescences & $3,5-4,0$ \\
Phosphorus & gametogenesis- ovary & $0,55-0,60$ \\
Potassium & tissue formation & $1,5-1,7$ \\
Calcium & flowering» & $1,2-1,7$ \\
Magnesium & & & $0,2-0,3$ \\
\hline Nitrogen & & aging of the seed & $2,7-3,0$ \\
Phosphorus & embryo & $0,22-0,28$ \\
Potassium & «ovary development» & $1,2-1,4$ \\
Calcium & & $1,4-1,8$ \\
Magnesium & & $0,8-1,0$ \\
\hline
\end{tabular}

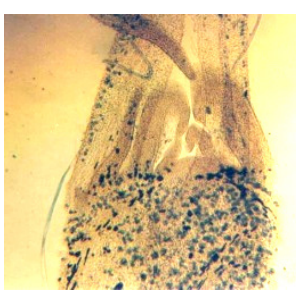

A

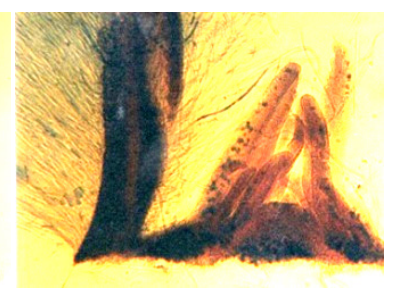

B

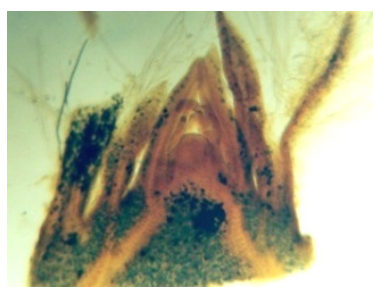

$\mathrm{C}$

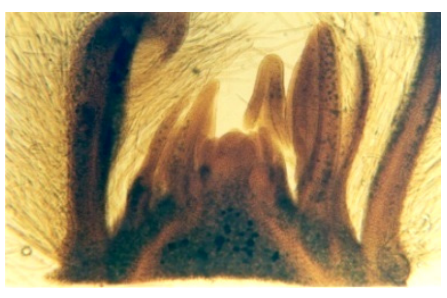

D

Figure 3. Stages of the transition from vegetative development to generative on 'Idared': a - transition to the formation of the primary hillock of inflorescence axis, $b$ - the development of the primary hillock of inflorescence, $\mathrm{c}$ - differentiation of inflorescence axis, $\mathrm{d}$ - branching of inflorescence axis, the formation of flowering hillock buds

The study of apical meristem differentiation in early July was carried out in parallel with the chemical analysis of apple tree nutritional applications. It was determined that the formation duration of hillock inflorescence axis mostly depends on the maximum and minimum air temperature fluctuations and the amount of precipitation. However, by regulating temperatures $\left(23-30^{\circ} \mathrm{C}\right)$ and increasing soil and air humidity at the initial stage there was a direct relation to the level of elements in the leaves of the apple tree shoots. Passage of the second half stage required the temperature optimization within $23-25{ }^{\circ} \mathrm{C}$. Analysis of the temperature regime in recent years in the south of Russia has revealed its absence. This period is characterized by the fact that the maximum daily temperature is raised to $40{ }^{\circ} \mathrm{C}$ with lack of precipitation. Thus despite the presence of low-volume irrigation, there significant wind (up to $12-15 \mathrm{mps}$ ) coupled with low humidity. The environmental conditions are a crucial factor in the duration of the period of generative formation of the apple tree. The intensity is significantly reduced due to stabilization of the hydrothermal factors which are close to optimal. Differentiation stage of the inflorescence axis, branching the inflorescence axis and formation of flowering hillock buds is resumed in the middle or end of August. During the activation of the process we analyzed changing of the chemical composition of apple tree leaves. The range of the basic mineral elements content were defined (\%): $\mathrm{N}-1,8-2,2 ; \mathrm{P}-$ $0,18-0,30 ; \mathrm{K}-1,0-1,7 ; \mathrm{Ca}-1,4-2,3 ; \mathrm{Mg}-0,2-1,0$. The highest values of nitrogen, potassium and magnesium have been identified against the background of foliar nutrition of plant by aqueous solutions of complex mineral fertilizers. These results were also confirmed by tissue analysis. Content of mineral (mobile) forms of the elements in the leaves of the shoots exceeded the control variant result (without fertilizers) on $3-5 \%$ (calcium) and $3-15 \%$ (magnesium).

The ratio of the main elements in the leaves of shoots was analyzed to determine the quality of apple tree nutrition in various stages of organogenesis (Table 2). According to the results the most significant changes in the content of the common forms of nitrogen and potassium were detected by using the foliar nutrition.

The positive effect of leaf treatments was confirmed by the physiological state of trees, that was diagnosed by the content and stability level of amino acids, pigments, bound form of water in the leaves, and changes in its morphoanatomical structure (thickness increasing of the parenchyma palisade layer from 30 to $60 \%$ ).

During the growing season the highest total content of 14 diagnoses of free amino acids were detected in the variant with the consistent using the nutrition by fertilizers 18-18-18 $+\mathrm{Mg}+\mathrm{S}$ and $\mathrm{N} 12 \mathrm{P} 12 \mathrm{~K} 35+\mathrm{Mg}+\mathrm{S}$. Amino acid content distinguished by seasonal stability: methionine (110-160 $\mathrm{mg} / \mathrm{kg})$, arginine $(60-100 \mathrm{mg} / \mathrm{kg})$, proline $(55-90 \mathrm{mg} / \mathrm{kg})$. Increases in pigment content in leaves from 4 to $20 \%$ were observed: 1) in the spring-summer period (fruit size 2.5-3.0 $\mathrm{cm}$ ), 2) during the differentiation of the bud (July) and 3) fruit maturation (August-September) (Figures 4 and 5).The highest content of the bound form of water in the shoot leaves during a period of high-temperature summer stress was defined in apple tree breed Prikubanskoe.(Figure 4, 5).

We defined by systems analysis method a direct correlation between chlorophyll $(a+b)$ and carotene sum content and content of common forms of nitrogen $(r=0,83$ and $\mathrm{r}=0,79$ respectively) and potassium $(\mathrm{r}=0,70$ and $\mathrm{r}=$ 0,75 respectively) in leaves shoots. We could see the content increasing of free amino acids (arginine, methionine, proline) against the background of leaf treatments. 
Table 2. The ratio of the mineral elements in the leaves of apple tree shoots on M9 rootstock

\begin{tabular}{|c|c|c|c|c|c|}
\hline \multirow[t]{2}{*}{ Variant } & \multirow[t]{2}{*}{ Organogenesis stage } & \multicolumn{4}{|c|}{ Ratio of gross forms of elements } \\
\hline & & $\mathrm{N}: \mathrm{P}: \mathrm{K}$ & $\mathrm{N}: \mathrm{P}$ & $\mathrm{N}: \mathrm{K}$ & $\frac{\mathrm{K}+\mathrm{Mg}}{\mathrm{Ca}}$ \\
\hline \multicolumn{6}{|c|}{ Apple-tree breed Idared } \\
\hline Control (without fertilizers) & \multirow{2}{*}{$\begin{array}{c}\text { gametogenesis - ovary tissue formation } \\
\text { (April) }\end{array}$} & $62: 6: 32$ & 9,5 & 1,93 & 1,95 \\
\hline $\begin{array}{l}\text { Foliar nutrition with aqueous solutions of } \\
\text { complex mineral fertilizers }\end{array}$ & & $65: 6: 29$ & 10,6 & 2,64 & 1,71 \\
\hline Control (without fertilizers) & \multirow{2}{*}{$\begin{array}{l}\text { differentiation of apical meristem } \\
\text { (July-August) }\end{array}$} & $65: 6: 29$ & 10,0 & 2,30 & 0,90 \\
\hline $\begin{array}{c}\text { Foliar nutrition with aqueous solutions of } \\
\text { complex mineral fertilizers }\end{array}$ & & $66: 7: 27$ & 9,0 & 2,40 & 1,10 \\
\hline \multicolumn{6}{|c|}{ Apple-tree breed Prikubanskoe } \\
\hline Control (without fertilizers) & \multirow{2}{*}{$\begin{array}{c}\text { gametogenesis - ovary tissue formation } \\
\text { (April) }\end{array}$} & $61: 7: 32$ & 9,2 & 1,88 & 1,75 \\
\hline $\begin{array}{c}\text { Foliar nutrition with aqueous solutions of } \\
\text { complex mineral fertilizers }\end{array}$ & & $64: 6: 30$ & 9,8 & 2,17 & 1,71 \\
\hline Control (without fertilizers) & \multirow{2}{*}{$\begin{array}{l}\text { differentiation of apical meristem } \\
\text { (July-August) }\end{array}$} & $66: 6: 28$ & 10,0 & 2,40 & 0,80 \\
\hline $\begin{array}{l}\text { Foliar nutrition with aqueous solutions of } \\
\text { complex mineral fertilizers }\end{array}$ & & $67: 7: 26$ & 10,0 & 2,60 & 0,70 \\
\hline
\end{tabular}

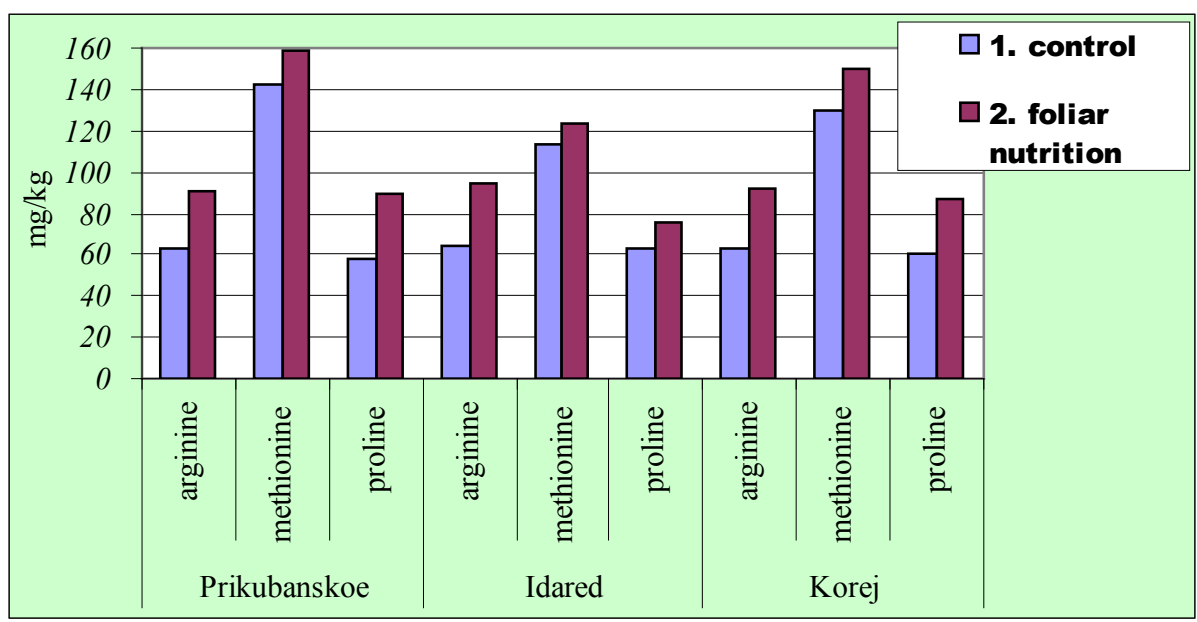

Figure 4. Amino acids content in the leaves of apple shoots

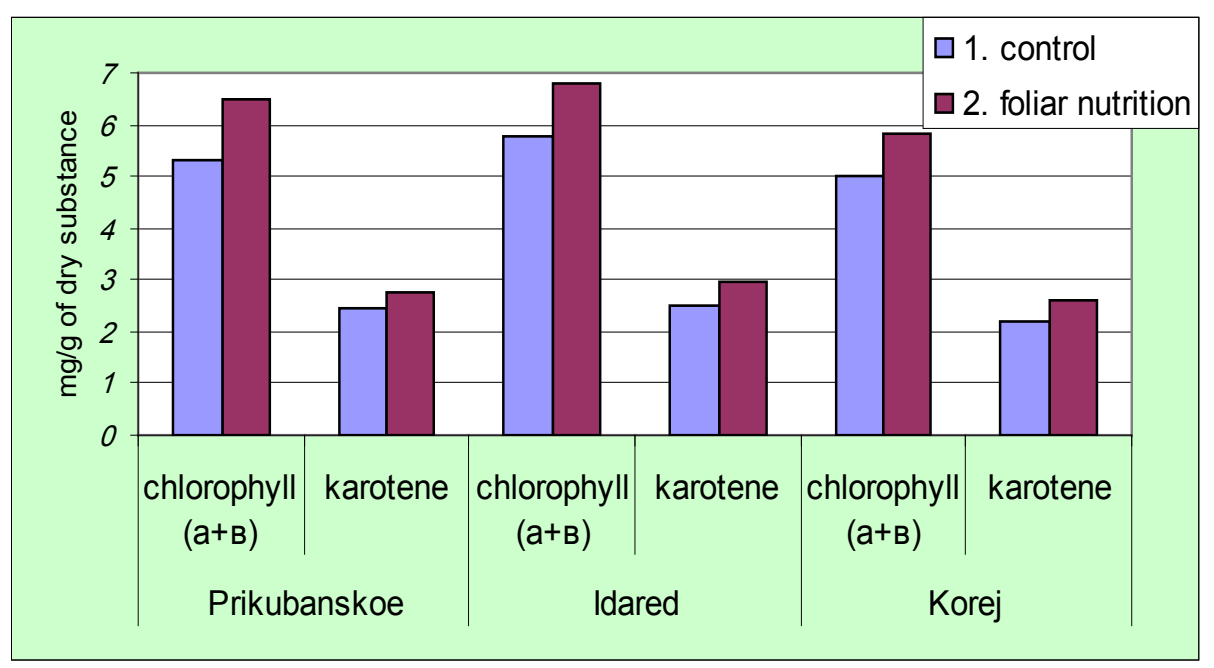




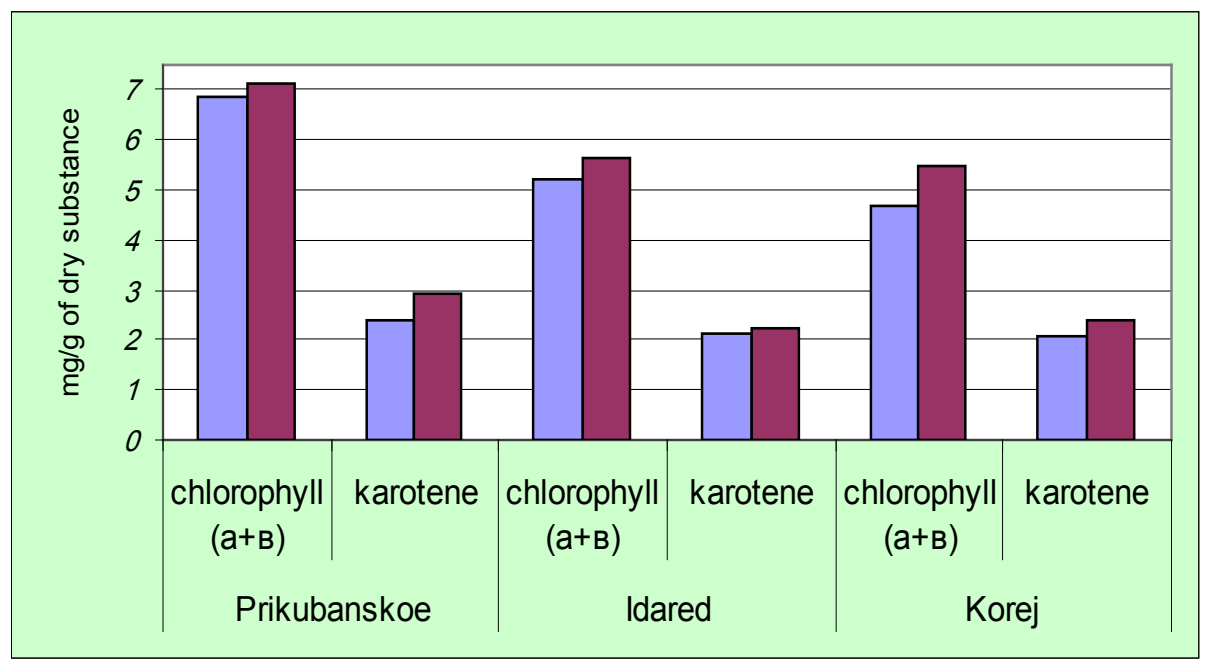

2

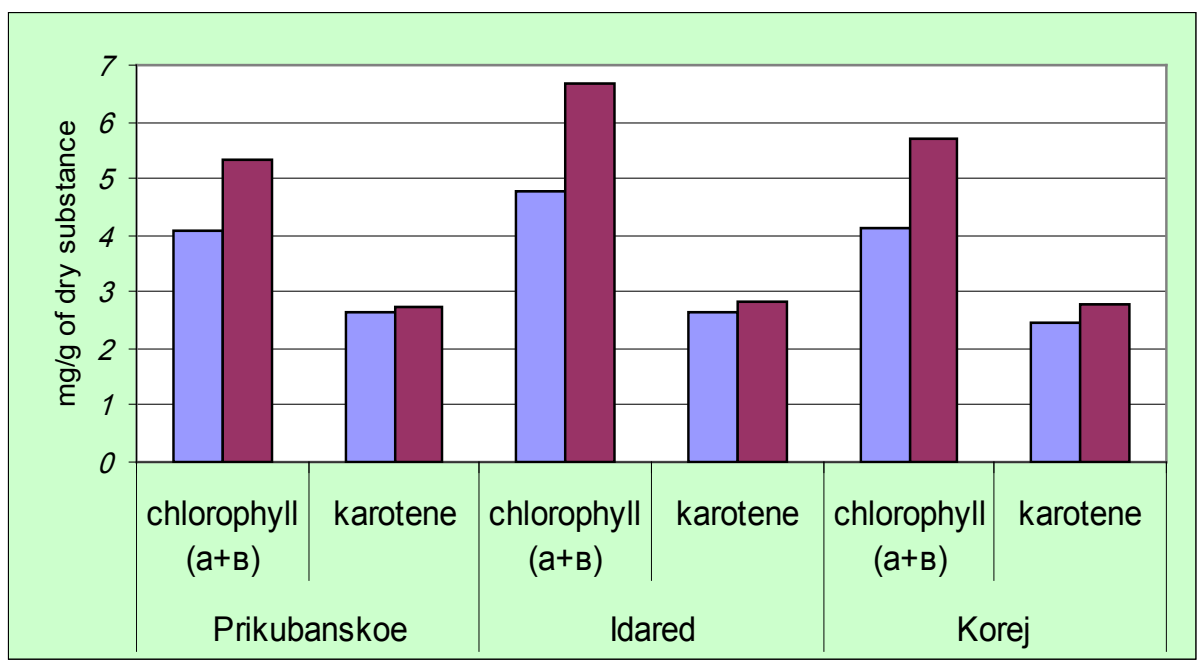

3

Figure 5. Pigment content in leaves of apple shoots: 1) in the spring-summer period, and 2) in the summer period of the bud differentiation and 3) during fruit maturation (August-September), average data

\section{Conclusion}

During this study we examined the development and formation process of fruit-bearing in apple cultivars 'Idared', 'Prikubanskoe' and 'Korej' on M9 rootstock in soil and climatic conditions of the south of Russia. The method of biological control of plant development in conjunction with chemical analysis has allowed a better understanding of apple tree mineral nutrition needs during different stages of organogenesis, to identify the critical periods in the seasonal development. Morphophysiological and agro-meteorological observations allowed establishing the impact of environmental factors on the rate of developmental stages and phases of the fruit-bearing apple trees. Integrated chemical analysis is the determination of the extent of the stabilization impact of foliar nutrition with aqueous solutions of mineral fertilizers on the adaptive properties of fruit crops during the growing season in the south of Russia.

In the variant of consistent fertilizer use during the season with a composition of 18-18-18 $+\mathrm{Mg}+\mathrm{S}$ and N12P12K35+ $\mathrm{Mg}+\mathrm{S}$, the most significant and statistically confirmed change was found in morphoanatomical sheet structures with the most plasticity: layer thickening of palisade parenchyma in the mesophyll, increasing the total thickness of the lamina. Microscopy confirmed the increase in the row number of palisade cells of leaf tissue, the location of the main chloroplast concentration. By this fact we tend to explain the increasing of chlorophyll content in the leaves against the background of the higher content of gross and mineral forms of elements in the leaves. In addition, during the second half of vegetation using the nutrition with higher potassium content had a positive effect contributing to optimize hydration of cells and to reduce the duration of the differentiation period. 
We defined the effect of foliar nutrition with aqueous solutions of complex mineral fertilizers on the mode of nutrition and the intensity of the morphoformation processes of apple trees. The periods of plant foliar nutrition have been installed and physiologically well-grounded and the best brand of fertilizer, that promotes the optimization of the apple-tree nutrition in the region, has been determined.

Systems analysis of short and long-term dynamics of the examined components allowed us to adequately interpret the results of the research and also to establish an information model «agrochemistry_orchard.db» for the development of precision technology of forming a productive garden cenosis.

\section{Acknowledgements}

We are very grateful to experts for their appropriate and constructive suggestions to improve this template.

\section{REFERENCES}

[1] A.I. Uskov Organogenesis of apple-tree, Kolos, Moscow, 1967.

[2] L.L. Buntsevich Morphophysiological characteristics of the formation of apple-tree (Malus domestica Borkh) , Prosveshenie-Yug, Krasnodar, 2012.

[3] N.N. Sergeeva, L.L. Buntsevich. Methodological aspects of the nutrition diagnosis of fruit crops, Theoretical journal "Herald of the Russian Academy of Agricultural Sciences", № 2, 48-50, 2010.
[4] I.S. Isaeva. Morphophysiology of fruit plants, Moscow State University, Moscow, 1974.

[5] V.P. Kryschenko. Methods of quality assessment of plant products, Kolos, Moscow, 1983.

[6] K.E. Ginsburg, G.M. Shcheglova, E..V Vulfius. The accelerated method of burning soil and plants, Edaphology, № 5, 89-96, 1963.

[7] N.N. Sergeeva, L.L. Buntsevich, N.G. Pestova. Integrated using of chemical diagnosis methods and biological control for studing a nutrient regime of fruit crops. Methodological and analytical support for research on gardening, North Caucasian Regional Research institute of Horticulture and Viticulture, Moscow, 2010, p. 121-126.

[8] The agrochemical research methods of soil (tutorial, ed. A. Sokolov), Science, Moscow, 1975.

[9] M.V. Zakharova, G.K. Kiselev, G.V. Lafar, Y.F. Yakuba. The procedure of extraction sample preparation of plant facilities on microwave mineralizer "Minotaur 1", North Caucasian Regional Research institute of Horticulture and Viticulture, Moscow, 2010, p. 271-273.

[10] Y.F. Yakuba. Application of microwave extraction with high-performance capillary electrophoresis for the analysis of the vegetative organs of plants, International conference, Moscow, 2004.

[11] M.V. Zakharova, I.A. Ilina, G.K. Kiselev, G.V. Lafar, Y.F. Yakuba. Methods of determining the mass concentration of ammonium cations, potassium, sodium, magnesium and calcium in the materials of plant origin, North Caucasian Regional Research institute of Horticulture and Viticulture, Moscow, 2010, p. 273-278.

[12] M.V. Zakharova, I.A. Ilina, G.V. Lafar, Y.F. Yakuba. Methods of determining the mass concentration of free amino acids, North Caucasian Regional Research institute of Horticulture and Viticulture, Moscow , 2010, p . 289-295. 